\title{
Individual responses of dairy cows to a 24-hour milking interval
}

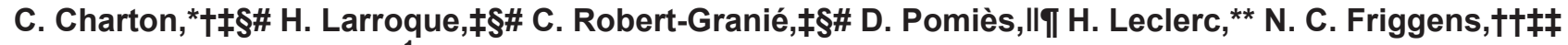 \\ and J. Guinard-Flament* ${ }^{1}$ \\ *INRA, UMR 1348 PEGASE, 65 Rue de Saint-Brieuc, F-35042 Rennes Cedex, France \\ †AGROCAMPUS OUEST, UMR 1348 PEGASE, 65 Rue de Saint-Brieuc, F-35042 Rennes cedex, France \\ fINRA, UMR 1388 GenPhySE (Génétique, Physiologie et Systèmes d'Elevage), F-31326 Castanet-Tolosan, France \\ §Université de Toulouse, INP, ENSAT, UMR 1388 GenPhySE (Génétique, Physiologie et Systèmes d'Elevage), F-31326 Castanet-Tolosan, \\ France \\ \#Université de Toulouse, INP, ENVT, UMR 1388 GenPhySE (Génétique, Physiologie et Systèmes d'Elevage), F-31076 Toulouse, France \\ IIINRA, UMR1213 Herbivores, F-63122 Saint-Genès-Champanelle, France \\ IClermont Université, VetAgro Sup, UMR1213 Herbivores, BP 10448, F-63000 Clermont-Ferrand, France \\ ${ }^{* *}$ Institut de l'Elevage, UMT 3G, Domaine de Vilvert, Jouy-en-Josas, France \\ ††INRA UMR 0791 Modélisation Systémique Appliquée aux Ruminants, 16 rue Claude-Bernard, Paris 75231, France \\ $\ddagger \ddagger$ AgroParisTech UMR 0791 Modélisation Systémique Appliquée aux Ruminants, 16 rue Claude-Bernard, Paris 75231, France
}

\section{ABSTRACT}

Some dairy farmers opt to omit one milking, either incidentally or weekly, without changing other milking times. This practice entails an extended milking interval of $24 \mathrm{~h}$ (24h-MI), which is associated with a decrease in milk yield. This decrease varies among cows and could be partly due to factors such as stage of lactation and milk yield level. The aim of this study was to describe the average and individual responses in terms of loss and carryover effects of a $24 \mathrm{~h}-\mathrm{MI}$ on milk yield. The influence of factors such as parity, stage of lactation, and milk yield potential were investigated, together with response repeatability. Our trial used 292 Holstein-Friesian cows, and consisted of 3 successive periods: 1 wk of twice-daily milking (TDM) as a control, one $24 \mathrm{~h}-\mathrm{MI}$, and then $13 \mathrm{~d}$ of TDM. The number of observations per cow ranged from 1 to 9 , with no more than three $24 \mathrm{~h}-\mathrm{MI}$ per lactation. The $24 \mathrm{~h}-\mathrm{MI}$ reduced milk yield by $23 \%$ (7.8 $\mathrm{kg}$ on average) and milk lactose content by $2.6 \mathrm{~g} / \mathrm{kg}$ on the $24 \mathrm{~h}-\mathrm{MI}$ day. Milk fat and protein content, and somatic cell score increased by $3.0 \mathrm{~g} / \mathrm{kg}, 0.5 \mathrm{~g} / \mathrm{kg}$, and 0.4 units, respectively. No significant carryover effect was found of a $24 \mathrm{~h}-\mathrm{MI}$ on milk yield or milk composition 2 wk after resumption of TDM. Milk yield loss and recovery varied widely (coefficient of variation $62 \%$ ), and the relationship between milk loss and milk recovery showed substantial variation (residual standard deviation $2.1 \mathrm{~kg} / \mathrm{d}$ ). Cows with

Received May 5, 2015.

Accepted December 5, 2015.

${ }^{1}$ Corresponding author: Jocelyne.Flament@agrocampus-ouest.fr a greater milk potential level lost more milk yield but recovered more milk, with no influence on recovery:loss ratio. Cows in early lactation recovered the lost milk yield faster. Repeatability of the responses to a $24 \mathrm{~h}-\mathrm{MI}$ was $44 \%$ for milk yield loss $(\mathrm{kg} / \mathrm{d}), 57 \%$ for relative milk yield loss (\%), 33\% for milk yield recovery $(\mathrm{kg} / \mathrm{d})$, and $0 \%$ for milk recovery:loss ratio (\%), suggesting a genetically determined ability to limit loss when one milking is omitted. To conclude, a $24 \mathrm{~h}-\mathrm{MI}$ caused higher milk yield losses than reported in previous studies. Stage of lactation, estimated potential milk yield level, and parity explained the cows' response to the $24 \mathrm{~h}-\mathrm{MI}$, but did not account for all the individual variability.

Key words: dairy cow, 24-hour milking interval, milk loss and recovery, repeatability

\section{INTRODUCTION}

In most dairy systems, cows are milked twice daily to maximize milk collected per day with an acceptable labor cost. However, some farmers omit one milking weekly to reduce labor input, allow more flexibility in labor management (Pomiès and Rémond, 2008), or adapt to unforeseen circumstances (milking machine failure, milker's unavailability, and so on). In such cases, farmers either omit one milking without changing other milking times to keep their work pattern (milking and feeding routine), or adjust the length of milking intervals by postponing the previous milking (Ayadi et al., 2003; Meffe et al., 2003).

The omission of one milking without changing milking times entails an extended milking interval of 24 $\mathrm{h}$ (24-h milking interval, 24h-MI) and is associated with an immediate decrease in milk yield observed on the day of milking omission, and carryover effects on 
Table 1. Number of observations, year, month, feeding conditions, parity, and stage of lactation per cohort

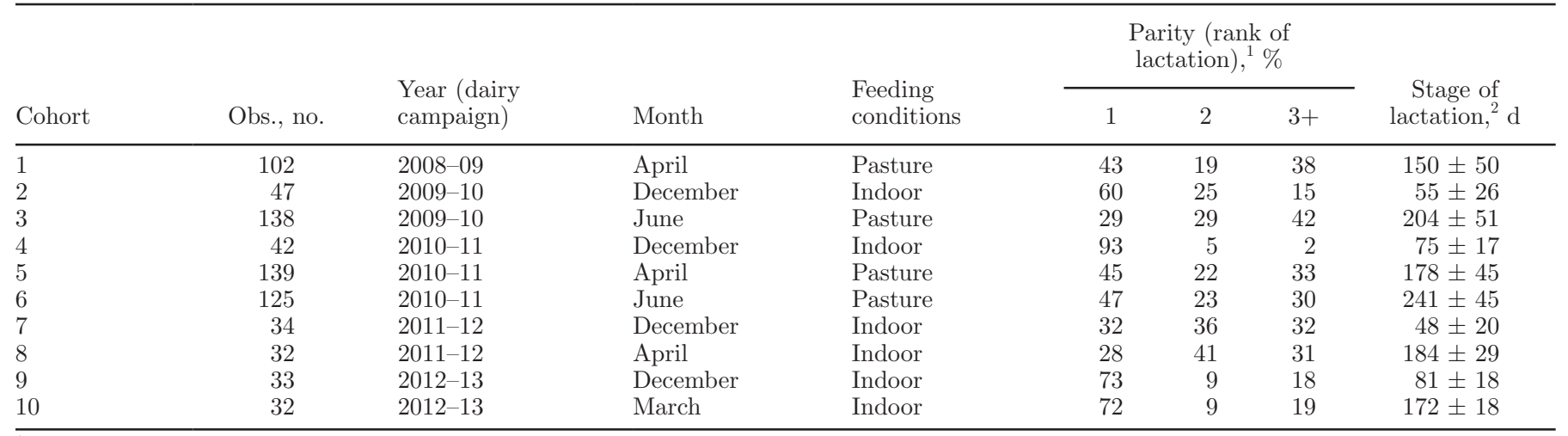

${ }^{1} 1=$ first lactation, $2=$ second lactation, $3+=$ third lactation and plus.

${ }^{2}$ Mean \pm SD.

milk yield, with a gradual return to initial state in the next 2 d (Labussière and Coindet, 1968; Radcliffe et al., 1973). In dairy cows the rate of milk secretion is known to decrease curvilinearly after 16 to $18 \mathrm{~h}$ of milk accumulation in the udder, so that the longer the milking intervals, the more marked are the milk losses and carryover effects (Elliott et al., 1960; Wheelock et al., 1966; Stelwagen et al., 2008).

Studies describing the average effects of using a $24 \mathrm{~h}-\mathrm{MI}$ by omitting one milking per week reported an average decrease in milk yield of up to $7.5 \%$ over 2 lactations (Labussière and Coindet, 1968), 13\% over the entire lactation (Roguinsky et al., 1972), 3.5\% over 12 mo (Radcliffe et al., 1973), $10 \%$ over 8 wk (Pomiès and Rémond, 2000), and no significant variations over the last 10 wk of lactation (O'Brien et al., 2002). These decreases in milk yield are relatively low, but vary among studies. Wheelock et al. (1966) and Radcliffe et al. (1973) report an individual variability in cows' responses. This individual variability could depend on factors such as stage of lactation, parity, and milk yield potential. Radcliffe et al. (1973) reported greater milk yield losses for high-producing cows in early lactation. Accordingly, Elliott et al. (1960) reported that one of the main factors affecting the decline in the rate of milk secretion with increasing milking interval was the yield level of cows, independent of the stage of lactation.

However, these studies were performed on limited number of cows $(\mathrm{n}<50)$, which prevented the authors from determining the influence of these factors. The aim of our study was thus to describe the average and individual responses in terms of loss and carryover effects of a 24h-MI on milk yield and composition using a larger data set (289 dairy cows). The influence of breeding factors, such as parity, stage of lactation, and milk yield potential were investigated, together with response repeatability.

\section{MATERIALS AND METHODS}

\section{Experimental Design}

To describe responses of dairy cows to a 24h-MI, 292 Holstein dairy cows from the INRA experimental farm of Méjusseaume $\left(48.11^{\circ} \mathrm{N}, 1.71^{\circ} \mathrm{W}\right.$; Brittany, France) were used in compliance with the National Legislation on Animal Care (French Ministry of Agriculture certification No. C35-275-23).

A total of $77524 \mathrm{~h}-\mathrm{MI}$ were performed, split into 10 cohorts $(32<\mathrm{n}<159)$, according to year, month, feeding, and housing conditions (Table 1).

Each 24h-MI consisted of 3 successive periods: $1 \mathrm{wk}$ control, when cows were milked twice daily (cTDM), $1 \mathrm{~d}$ of $24 \mathrm{~h}-\mathrm{MI}$ (morning milking omitted), and $13 \mathrm{~d}$ of twice-daily milking (TDM) to examine milk recovery. These $13 \mathrm{~d}$ were divided into 3 sub-periods: pTDM1 (d 1 after 24h-MI), pTDM2 (d 2 to 6 after 24h-MI), and pTDM3 (d 7 to 13 after 24h-MI). When milked twice daily, cows were milked at 0730 and $1630 \mathrm{~h}$. On the day of 24h-MI, cows were milked at $1630 \mathrm{~h}$.

Observations from cows that were dried off before the end of the experiment $(\mathrm{n}=20)$, with DIM greater than $311 \mathrm{~d}$ on $24 \mathrm{~h}-\mathrm{MI}$ day $(\mathrm{n}=30)$ or producing less than $10 \mathrm{~kg} / \mathrm{d}$ on cTDM $(\mathrm{n}=1)$ were removed from the data set. A total of 724 observations corresponding to 289 cows were kept for analysis.

A total of 216 cows underwent more than one $24 \mathrm{~h}-\mathrm{MI}$, and 73 cows only one. When the $24 \mathrm{~h}-\mathrm{MI}$ was repeated, the number of observations per cow ranged from 2 to 9 , with $101,52,40,15,3,1,3$, and 1 cows having $2,3,4$, $5,6,7,8$, and 9 observations, respectively, with no cow repeated inside a cohort. The number of observations per cow varied from 1 to 3 within lactation (no more than three $24 \mathrm{~h}-\mathrm{MI}$ per lactation per cow) and from 1 to 4 between lactations. 
Cows differed in parity, stage of lactation, and age at first calving both within and among cohorts (Table 1). Calving (seasonal calving) occurred between September and January. Age at first calving was around 24 or 34 mo, and $76 \%$ cows had their first calf at around 24 mo.

\section{Measurements, Sampling, and Analysis}

Milk yield was recorded at every milking in the milking parlor (rotary milking parlor, milk meter MM25, DeLaval France, Elancourt, France). Milk fat, protein, and lactose contents were determined from milk samples collected at each milking, 2 or $3 \mathrm{~d}$ a week during cTDM, pTDM1, pTDM2, and pTDM3 and on the 24hMI day. Somatic cell count was measured once a day on the same days. Milk fat, protein, and lactose contents were determined by infrared analysis (Milkoscan, Foss Electric, Hillerød, Denmark), and SCC with a Fossomatic cell counter (Foss Electric).

\section{Calculations}

For periods longer than $1 \mathrm{~d}$, milk yield and composition were averaged over $5 \mathrm{~d}$ (pTDM2) or $1 \mathrm{wk}$ (cTDM, pTDM3). Milk lactose content was transformed using a log scale due to the nonnormality of the data. The SCC was converted into SCS using the formula SCS $=\log _{2}$ $(\mathrm{SCC} / 100,000)+3$, where SCC is expressed in units of 1,000 cells/mL (Rupp and Boichard, 1997).

Milk yield loss $(\mathrm{kg} / \mathrm{d})$ was computed as the difference between 24h-MI and cTDM. Relative milk yield loss (\%) was milk yield loss $(\mathrm{kg} / \mathrm{d})$ divided by cTDM milk yield, multiplied by 100 . Milk yield recovery $(\mathrm{kg} / \mathrm{d})$ was computed as the difference between pTDM3 and 24h-MI. Milk recovery:loss ratio (\%) was computed as milk yield recovery $(\mathrm{kg} / \mathrm{d})$ divided by milk yield loss $(\mathrm{kg} / \mathrm{d})$, multiplied by 100 . The recovery:loss ratio was calculated for cows showing both a loss of milk yield when they switched to $24 \mathrm{~h}-\mathrm{MI}$, and a gain of milk yield when they switched back to TDM, which occurred for 620 challenges.

The changes expected to occur during a 21-d period of normal twice-daily milking throughout lactation were estimated according to calving month, age at first calving, milk year, parity, and DIM from a reference data set of Holstein-Friesian dairy cows from herds of the west of France with official milk recording (reference data set based on 89,399,603 test-day milking with an average of 312 cows per level (minimum 24, maximum 848); H. Leclerc, 2014, personal communication). These provided a reference against which to compare the changes from $21-\mathrm{d}$ periods including a $24 \mathrm{~h}-\mathrm{MI}$, and corrected daily milk yield, milk fat, protein, and SCS contents were calculated on this basis to estimate carryover effects of the $24 \mathrm{~h}-\mathrm{MI}$.

\section{Statistical Analyses}

All statistical analyses were performed using $\mathrm{R}$ software (R Core Team, The R Foundation for Statistical Computing, 2014, R: A Language and Environment for Statistical Computing, Version 3.0.2, Vienna, Austria, http://www.R-project.org). Data were analyzed using linear mixed models ( $\mathrm{R}$ package nlme, Pinheiro et al., 2013).

The evolution of milk yield and milk composition was analyzed with the following linear mixed model. Model 1 is

$$
\begin{aligned}
Y_{i j k l m n} & =\mu+\text { period }_{i}+\text { stage of lactation }_{j}+\text { parity }_{k} \\
& + \text { age at first calving } \\
& + \text { milk year }_{m} \\
& + \text { interactions }+\operatorname{cow}_{n}+\varepsilon_{i j k l m n},
\end{aligned}
$$

where $Y_{i j k l m n}$ is the dependent variable (corrected and noncorrected daily milk yield, milk fat, protein, and SCS contents and noncorrected lactose content); $\mu$ is the mean; the fixed effects tested are the period $i$ (cTDM, 24h-MI, pTDM1, pTDM2, pTDM3), the stage of lactation $j$, the parity $k$, the age at first calving $l$, the milk year $m$, and the 2-way interactions between the fixed effects; the random effect of the cow (assumed to be normally distributed) is $n$; and $\varepsilon_{i j k l m n}$ is the residual error associated with each ijklmn observation. The fixed effects other than period were coded as follows: primiparous $(\mathrm{n}=340)$ were distinguished from cows in second lactation $(\mathrm{n}=162)$ and third or more lactation $(\mathrm{n}=222)$. Stage of lactation was divided into 4 classes: early lactation (24-50 DIM, $\mathrm{n}=59)$, peak of lactation (51-100 DIM, $\mathrm{n}=119)$, mid lactation (101-180 DIM, $\mathrm{n}=219)$, and late lactation (181-311 DIM, $\mathrm{n}=327)$. Age at first calving was divided into 2 classes: first calving at around $24 \pm 5 \mathrm{mo}(\mathrm{n}=551)$ and at $34 \pm$ 5 mo $(\mathrm{n}=173)$. The milk year effect was defined in 3 levels $(2008-2010, \mathrm{n}=287 ; 2010-2011, \mathrm{n}=306$; and 2011-2013, $\mathrm{n}=131$ ). In preliminary analyses, stage of gestation, feeding (access to pasture versus indoor feeding only), and initial levels of fat, protein and SCS contents were also included, but were not found to be significant.

To use the milk yield level as an explanatory variable for the response to $24 \mathrm{~h}-\mathrm{MI}$, milk yield during period cTDM was adjusted for environmental factors using the following linear model. Model 2 is 


$$
\begin{aligned}
& Y_{j k l m}=\mu+\text { stage of lactation }{ }_{j}+\text { parity }_{k} \\
& + \text { age at first calving }{ }_{l}+\text { milk year }_{m} \\
& + \text { stage of lactation }{ }_{j} \times \text { parity }_{k}+\text { parity }_{k}
\end{aligned}
$$

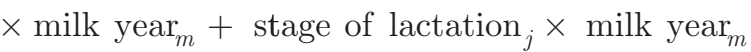

$$
\begin{aligned}
& +\varepsilon_{j k l m},
\end{aligned}
$$

where $Y_{j k l m}$ is the milk yield during period cTDM and the other effects are as described above. Potential milk yield level was then defined as $\frac{Y_{j k l m}-\hat{Y}_{j k l m}}{\hat{Y}_{j k l m}}$, where $\hat{Y}_{j k l m}$ is the value predicted from model 2 . These values were averaged for each lactation of the cow and coded in 4 levels using the limits: $[-0.38$ to $-10 \%],[-10 \%$ to 0$]$, [0 to $10 \%$ ], and [10 to $36 \%]$, which corresponds to the quartiles of a normal distribution.

Milk yield loss, relative milk yield loss, and milk yield recovery were analyzed according to the following linear mixed model. Model 3 is

$$
\begin{aligned}
& Y_{\text {jkmno }}=\mu+\text { stage of lactation }{ }_{j}+\text { parity }_{k}
\end{aligned}
$$

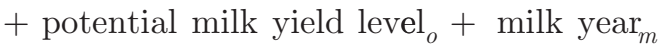

$$
\begin{aligned}
& + \text { stage of lactation }_{j} \times \text { parity }_{k} \\
& + \text { stage of lactation }_{j} \times \text { milk year }_{m}+\text { parity }_{k}
\end{aligned}
$$

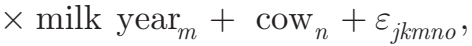

where $Y_{j k m n o}$ is the dependent variable (milk yield absolute and relative loss and recovery); $\mu$ is the mean; the fixed effects are the stage of lactation $j$, the parity $k$, the potential milk yield level $o$, the milk year $m$, and the 2-way interactions between the fixed effects; the random effect of the cow (assumed to be normally distributed) is $n$; and $\varepsilon_{j k m n o}$ is the residual error associated with each jkmno observation.

The model built to analyze rate of milk recovery was identical to model 3, except for interactions. The interactions parity $\times$ stage of lactation and parity $\times$ milk year were not significant, but a significant potential milk yield level $\times$ milk year interaction was found.

Results for fixed effects and interactions were expressed as least squares means and were computed using the lsmeans package (Lenth, 2014). Differences were considered significant at $P<0.05$.

Repeatability of cows' response in terms of milk yield loss $(\mathrm{kg} / \mathrm{d}$ and \%) and recovery $(\mathrm{kg} / \mathrm{d})$ between each $24 \mathrm{~h}-\mathrm{MI}$ were computed by dividing the variance explained by the cow effect by total variance, multiplied by 100 .

Pearson correlations were computed between milk yields at different experimental periods, milk losses $(\mathrm{kg} / \mathrm{d}, \%)$, milk yield recovery $(\mathrm{kg} / \mathrm{d})$, and milk recovery:loss ratio (\%).

\section{RESULTS AND DISCUSSION}

During the control week (cTDM), milk yield averaged $28.5 \pm 6.33 \mathrm{~kg} / \mathrm{d}$, milk fat content averaged 36.9 $\pm 4.76 \mathrm{~g} / \mathrm{kg}$, milk protein content averaged $30.1 \pm 2.4$ $\mathrm{g} / \mathrm{kg}$, milk lactose content averaged $48.0 \pm 2.02 \mathrm{~g} /$ $\mathrm{kg}$, and SCS averaged $2.58 \pm 1.63$ units. These data showed marked individual variations, especially for milk yield, which varied from 12.9 to $52.3 \mathrm{~kg} / \mathrm{d}$, and milk fat content, which varied from 18.9 to $52.9 \mathrm{~g} / \mathrm{kg}$. Milk protein and lactose contents showed less between-cow variability: from 24.2 to $38.4 \mathrm{~g} / \mathrm{kg}$ for protein content and from 32.2 to $53.1 \mathrm{~g} / \mathrm{kg}$ for lactose content. Milk SCS varied widely, from -1.32 to 9.18 units (which corresponds to around 5,000 and more than 7 million cells $/ \mathrm{mL}$, respectively). This variability originated from the experimental design using 724 observations obtained over several years from 289 cows at different parity, stage of lactation, and age at first calving inside cohorts (Table 1). It remained steady over experimental periods except for milk fat and lactose content, whose coefficients of variation increased by $45 \%$ when one milking was omitted, and returned to their initial levels when cows resumed TDM.

\section{Average Effects of a 24h-MI on Milk Yield and Composition}

The omission of one milking led to an average decrease in milk yield of $6.3 \mathrm{~kg} / \mathrm{d}(22.1 \%$; Table 2). Milk yield and composition (except for milk lactose content) were corrected from the variations occurring in the course of lactation (according to model 1). In response to milking omission, least squares means of milk yield decreased by $7.8 \mathrm{~kg} / \mathrm{d}(23.4 \%)$, and milk lactose content decreased by $2.6 \mathrm{~g} / \mathrm{kg}$, whereas milk fat and protein contents and milk SCS increased by $3.2 \mathrm{~g} /$ $\mathrm{kg}, 0.5 \mathrm{~g} / \mathrm{kg}$ and $0.41 \mathrm{units}$, respectively (Table 3 ). The decrease in milk yield was greater than the $10 \%$ milk loss observed by Stelwagen et al. (2008) with one 24h$\mathrm{MI}$ and the $14 \%$ losses observed in 7 cows by Wheelock et al. (1966). However, Wheelock et al. (1966) reported a high variability in responses between cows, milk yield losses varying between 1 and $31 \%$. The decrease in milk lactose content and the increase in milk fat and protein contents and SCS support earlier findings (Labussière and Coindet, 1968; Pomiès and Rémond, 2000). Most changes in milk composition can be related to changes in mammary epithelial tissue permeability. Alveolar distension occurring in reaction to 18 to $24 \mathrm{~h}$ milk ac- 
Table 2. Milk absolute and relative loss when switching from twice-daily milking control period (cTDM) to a $24 \mathrm{~h}$ milking interval (24h-MI), milk recovery and rate of milk recovery when switching back from 24h-MI to twice daily milking (pTDM3, d 7 to 13 after 24h-MI)

\begin{tabular}{|c|c|c|c|c|c|c|}
\hline Item & Mean & Minimum & Maximum & $\mathrm{SD}$ & $\mathrm{CV}$ & $\mathrm{N}^{1}$ \\
\hline Relative loss (milk yield), ${ }^{3} \%$ & -21.3 & -52 & 21.6 & 11.54 & 54.2 & 724 \\
\hline
\end{tabular}

${ }^{1}$ Number of observations.

${ }^{2}$ Difference between $24 \mathrm{~h}-\mathrm{MI}$ and cTDM milk yields.

${ }^{3}$ Difference between $24 \mathrm{~h}-\mathrm{MI}$ and cTDM milk yields divided by cTDM milk yields $(\times 100)$.

${ }^{4}$ Difference between 24h-MI and pTDM3 milk yields.

${ }^{5}$ Difference between $24 \mathrm{~h}-\mathrm{MI}$ and pTDM3 milk yields divided by difference between cTDM and 24h-MI milk yields $(\times 100)$.

${ }^{6}$ Computed on a subset of 620 cows.

cumulation is known to impair tight junctions $(\mathbf{T J})$ between mammary epithelial cells (MEC; Stelwagen et al., 1994; Davis et al., 1999). Impaired TJ increases exchanges between the smaller components of milk and interstitial fluids, thereby leading to a leakage of milk lactose from milk to blood and an influx of proteins from blood into the milk compartment (Stelwagen et al., 1994; Stelwagen and Lacy-Hulbert, 1996; Auldist and Prosser, 1998). The increase in milk protein content observed with a $24 \mathrm{~h}-\mathrm{MI}$ could therefore be partly due to this influx. However, extended milking intervals stimulate multiple and complex physiological mechanisms, and changes in milk composition are not due solely to impaired TJ. An increase in milk fat content, for example, has been reported in extended milking intervals (Wheelock et al., 1966), and could be due to smaller changes in the regulation of milk fat globule secretion relative to that of milk aqueous phase components (Davis et al., 1999; Guinard-Flament et al., 2011b).

Average carryover effects of the $24 \mathrm{~h}-\mathrm{MI}$ on milk yield and composition were estimated $13 \mathrm{~d}$ after resuming TDM (pTDM3). Milk yield and fat and protein contents corrected from variations occurring in the course of lactation using data from official milk recording were not different from their control period levels (Table 3). In regard to milk lactose content, it was not possible to adjust for the trend with advancing lactation, because routine milk recording does not automatically record this. However, the nonsignificance of the unadjusted difference between cTDM and pTDM2 milk lactose content suggests no carryover effects of $24 \mathrm{~h}-\mathrm{MI}$ on milk lactose. To our knowledge, no study has focused on the long-term carryover effects of omitting one milking. Most studies describing cows' responses to an extended milking interval aim to determine the length of the recovery period necessary to resume initial milk production. These studies report that the length of this recovery period is different for milk yield, milk fat, and milk protein contents, and that the length of the full recovery period could be more than $48 \mathrm{~h}$ (Wheelock et al., 1966; Radcliffe et al., 1973). The present study, reporting no carryover effect of a $24 \mathrm{~h}-\mathrm{MI}$ on milk yield and composition 2 to $6 \mathrm{~d}$ (pTDM2) and 7 to $13 \mathrm{~d}$ (pTDM3) thus agrees with previous studies, showing, on average, a full recovery of milk yield within the 2 to $3 \mathrm{~d}$ following the 24h-MI.

However, although the 24h-MI results in an average loss of $22.1 \%$ of milk yield with no carryover effects, this figure hides a high variability of responses.

\section{Variability of Milk Yield Loss and Subsequent Milk Recovery Associated With a 24h-MI}

The correlations between milk yields during experimental periods are given in Table 4. Milk yield correla-

Table 3. Least squares means ( \pm SE) of period effect [twice daily milking control period (cTDM), $24 \mathrm{~h}$ milking interval (24h-MI), d 1 after 24h-MI (pTDM1), d 2 to 6 after 24h-MI (pTDM2), and d 7 to 13 after 24h-MI (pTDM3)] in model 1 on corrected milk yield and composition (milk lactose content excepted) corrected from variations expected in the course of lactation

\begin{tabular}{|c|c|c|c|c|c|}
\hline Item & cTDM & $24 \mathrm{~h}-\mathrm{MI}$ & pTDM1 & pTDM2 & pTDM3 \\
\hline
\end{tabular}

${ }^{\mathrm{a}-\mathrm{c}}$ Within each row, values with different superscript letters differ significantly $(P<0.05)$. 
Table 4. Pearson correlations between milk yields during experimental periods [twice daily milking control period (cTDM), $24 \mathrm{~h}$ milking interval period (24h-MI), d 1 after 24h-MI (pTDM1), d 2 to 6 after 24h-MI (pTDM2), and d 7 to 13 after 24h-MI (pTDM3)], and milk yield losses (kg/d, $\%)$ or recoveries $(\mathrm{kg} / \mathrm{d})$ and recovery:loss ratio $(\%)$ expressed as absolute or relative variations $(\mathrm{n}=725$ observations)

\begin{tabular}{|c|c|c|c|c|c|c|c|c|}
\hline Item & $\begin{array}{c}\text { cTDM, } \\
\text { kg/d }\end{array}$ & $\begin{array}{c}24 \mathrm{~h}-\mathrm{MI} \\
\mathrm{kg} / \mathrm{d}\end{array}$ & $\begin{array}{l}\text { pTDM1, } \\
\text { kg/d }\end{array}$ & $\begin{array}{l}\text { pTDM2, } \\
\text { kg/d }\end{array}$ & $\begin{array}{l}\text { pTDM3, } \\
\text { kg/d }\end{array}$ & $\begin{array}{l}\text { Loss, }^{1} \\
\mathrm{~kg} / \mathrm{d}\end{array}$ & $\begin{array}{c}\text { Relative } \\
\text { loss, }^{2} \\
\%\end{array}$ & $\begin{array}{c}\text { Recovery }{ }^{3} \\
\mathrm{~kg} / \mathrm{d}\end{array}$ \\
\hline \multicolumn{9}{|l|}{ Milk yield } \\
\hline $\mathrm{pTDM} 1, \mathrm{~kg} / \mathrm{d}$ & $0.88^{* * *}$ & $0.70 * * *$ & & & & & & \\
\hline $\mathrm{pTDM} 2, \mathrm{~kg} / \mathrm{d}$ & $0.97^{* * *}$ & $0.76^{* * *}$ & $0.90^{* * *}$ & & & & & \\
\hline $\mathrm{pTDM} 3, \mathrm{~kg} / \mathrm{d}$ & $0.95^{* * *}$ & $0.73^{* * *}$ & $0.85^{* * *}$ & $0.97^{* * *}$ & & & & \\
\hline Recovery:loss ratio, ${ }^{4,5} \%$ & $0.14^{* * *}$ & $0.10^{*}$ & $0.16^{* * *}$ & $0.27^{* * *}$ & $0.37^{* * *}$ & $-0.10^{*}$ & NS & $0.50^{* * *}$ \\
\hline
\end{tabular}

${ }^{1}$ Difference between $24 \mathrm{~h}-\mathrm{MI}$ and cTDM milk yields.

${ }^{2}$ Difference between $24 \mathrm{~h}-\mathrm{MI}$ and cTDM milk yields divided by cTDM milk yields $(\times 100)$.

${ }^{3}$ Difference between 24h-MI and pTDM3 milk yields.

${ }^{4}$ Difference between $24 \mathrm{~h}-\mathrm{MI}$ and pTDM3 milk yields divided by difference between cTDM and 24h-MI milk yield $(\times 100)$.

${ }^{5}$ Computed on a subset of 620 cows.

${ }^{* * *} P<0.001 ;{ }^{* *} P<0.01 ;{ }^{*} P<0.05$ indicate significant difference from $0 ;$ NS: $P<0.05$.

tions between the 24h-MI and any given TDM period were lower than those between TDM periods, indicating that the $24 \mathrm{~h}-\mathrm{MI}$ induced variable responses among cows on both milk loss and milk recovery. The high correlation between cTDM and pTDM3 periods $(\mathrm{r}=0.95)$ indicates that these responses were transient, and that most cows recovered their initial performance rank. These variable responses among cows on both milk loss and milk recovery suggest the presence of cows that are more tolerant toward this practice. Dairy cows that tolerate a $24 \mathrm{~h}-\mathrm{MI}$ could be defined by their ability to show a limited milk loss when undergoing a $24 \mathrm{~h}-\mathrm{MI}$, to recover as much milk as they lost, or both. Milk losses, recovery, and recovery:loss ratio were therefore studied as indicators of the ability of the cow to tolerate a 24h-MI.

As indicated by standard deviation, most cows lost between $2(-9.8 \%)$ and $10 \mathrm{~kg} / \mathrm{d}(-32.8 \%)$ when undergoing a 24h-MI, with an average loss of $6.3 \mathrm{~kg} / \mathrm{d}$ $(-21.3 \%$, Table 2$)$. As illustrated in Figure 1, this loss was highly variable $(\mathrm{CV}=62 \%)$, with cows losing as much as $21.6 \mathrm{~kg} / \mathrm{d}(-52 \%)$ and some cows gaining up to $4.0 \mathrm{~kg} / \mathrm{d}(21.6 \%)$. In pTDM3, cows on average recovered less milk yield $(4.8 \mathrm{~kg} / \mathrm{d})$ than they had lost $(6.3$ $\mathrm{kg} / \mathrm{d}$ ). This average $1.5 \mathrm{~kg} / \mathrm{d}$ difference between milk loss and recovery was mainly due to the variations occurring in the course of lactation, as previously shown by the correction of milk yield from changes occurring in the course of lactation (Table 3). As indicated by a negative correlation (Table 4), cows showing the highest milk losses were also those that had the highest milk recovery. However, the residual standard deviation of the regression of milk recovery on milk loss was 2.1 $\mathrm{kg} / \mathrm{d}$ (Figure 1), indicating a significant variation in the relationship between loss and recovery: some latelactation cows showed no positive recovery (Figure 1).

The present study showed a higher proportion of early lactation cows among those that recovered more than expected from the general regression (i.e., cows above the line in Figure 1), and a higher proportion of later-lactation cows among those that recovered less than expected (i.e., below the line in Figure 1). Cows in early lactation (24-50 DIM) recovered on average 0.95 $\mathrm{kg} / \mathrm{d}$ more than expected, whereas cows in late lactation (181-311 DIM) recovered on average $0.23 \mathrm{~kg} / \mathrm{d}$ less than expected.

Although significant, the correlation $(\mathrm{r}=-0.10)$ between recovery:loss ratio and milk loss $(\mathrm{kg} / \mathrm{d})$ was weak. Furthermore, recovery:loss ratio was not correlated with relative milk loss (\%), thus indicating that recovery:loss ratio could be independent of the quantity of milk lost. To our knowledge, such observations have been reported only once in the literature, but using once-daily milking over $3 \mathrm{wk}$ (Guinard-Flament et al., 2011a). Thus, to quantify cows' tolerance to $24 \mathrm{~h}-\mathrm{MI}$, it seems necessary to describe the 2 abilities, namely the ability to show limited losses ( $\mathrm{kg} / \mathrm{d}$ and \%) and the ability to recover as much milk as they lost (milk recovery:loss ratio, \%).

\section{Repeatability of Cows' Response between 24h-MI}

Repeatability of the cow responses to a $24 \mathrm{~h}-\mathrm{MI}$ were $44 \%$ for milk loss $(\mathrm{kg} / \mathrm{d}), 57 \%$ for relative milk loss (\%), $33 \%$ for milk recovery $(\mathrm{kg} / \mathrm{d})$, and $0 \%$ for milk recovery:loss ratio (\%). To our knowledge, repeatability 
of cows' responses to a 24h-MI has not been studied to date. Repeatability of cows' responses in cases of extended milking intervals has been described only by Carruthers et al. (1993) in the case of cows milked once a day for three 1-wk periods. The absolute milk loss repeatability observed in the present study seems consistent with the $49 \%$ repeatability reported by Carruthers et al. (1993). However, the $57 \%$ relative milk loss (\%) repeatability observed here was greater than the $41 \%$ they observed. As repeatability is known to constitute an upper limit of heritability, cow's milk loss when one milking is omitted could be a trait with a moderate heritability. Hence, the mammary gland's ability to tolerate disruption with $24 \mathrm{~h}-\mathrm{MI}$ could in part be genetically determined.

\section{Effects of Cows' Potential Milk Yield Level, Stage of Lactation, and Parity on Cows' Ability to Tolerate a $24 h-M I$}

Stage of gestation, feeding (access to pasture versus control feed), and initial levels of fat and protein contents and SCS did not significantly affect milk loss $(\mathrm{kg} / \mathrm{d}$ and $\%)$ or milk recovery $(\mathrm{kg} / \mathrm{d})$ in the present study.

The estimation of the potential milk yield level of the cow expresses the part of the milk yield during the control period that was not accounted for by the effects of stage of lactation, parity, age at first calving, milk year, or the interaction of these effects. This milk potential was thus considered as being the sum of the milk genetic potential of the cow and its permanent environment. As potential milk yield level was estimated as the residual from the model adjusting milk yield during the control period for breeding factors, it is assumed here that cows with the highest residuals had the highest milk potential. In the present study, higher potential milk yield level was associated with higher milk yield loss expressed in either absolute or relative value $(3.6 \mathrm{~kg} / \mathrm{d}$ and $6.3 \%$ difference between lowest $25 \%$ milk potential and highest $25 \%$ milk potential, respectively, Table 5). Milk recovery $(\mathrm{kg} / \mathrm{d})$ was also greater for cows with a higher potential milk yield $(+2.8 \mathrm{~kg} / \mathrm{d})$. Consequently, no significant effect of potential milk yield was found on milk recovery:loss ratio. The ability to demonstrate a strong milk recovery:loss ratio after a $24 \mathrm{~h}-\mathrm{MI}$ was not linked to a higher estimated milk potential.

Cows in early lactation (24-50 DIM) lost more milk (in both $\mathrm{kg} / \mathrm{d}$ and \%), but recovered more milk than cows in late lactation (Tables 6 and 7). Their response also showed a different time course compared with cows at peak, mid, and late lactation (Figure 2). Cows in early lactation recovered the lost milk sooner. At pTDM1, these cows (24-50 DIM) had already reached $78 \%$ of the total milk yield they ultimately recovered (at the pTDM3 period), whereas cows at peak (51-100 DIM), mid (101-180 DIM) and late (181-311 DIM) lactation had respectively reached only 65,44 , and $41 \%$ of the total milk yield they ultimately recovered.

Milk yield loss measured on the first day of oncedaily milking has been reported to be greater for cows having a smaller proportion of milk stored in the mam-

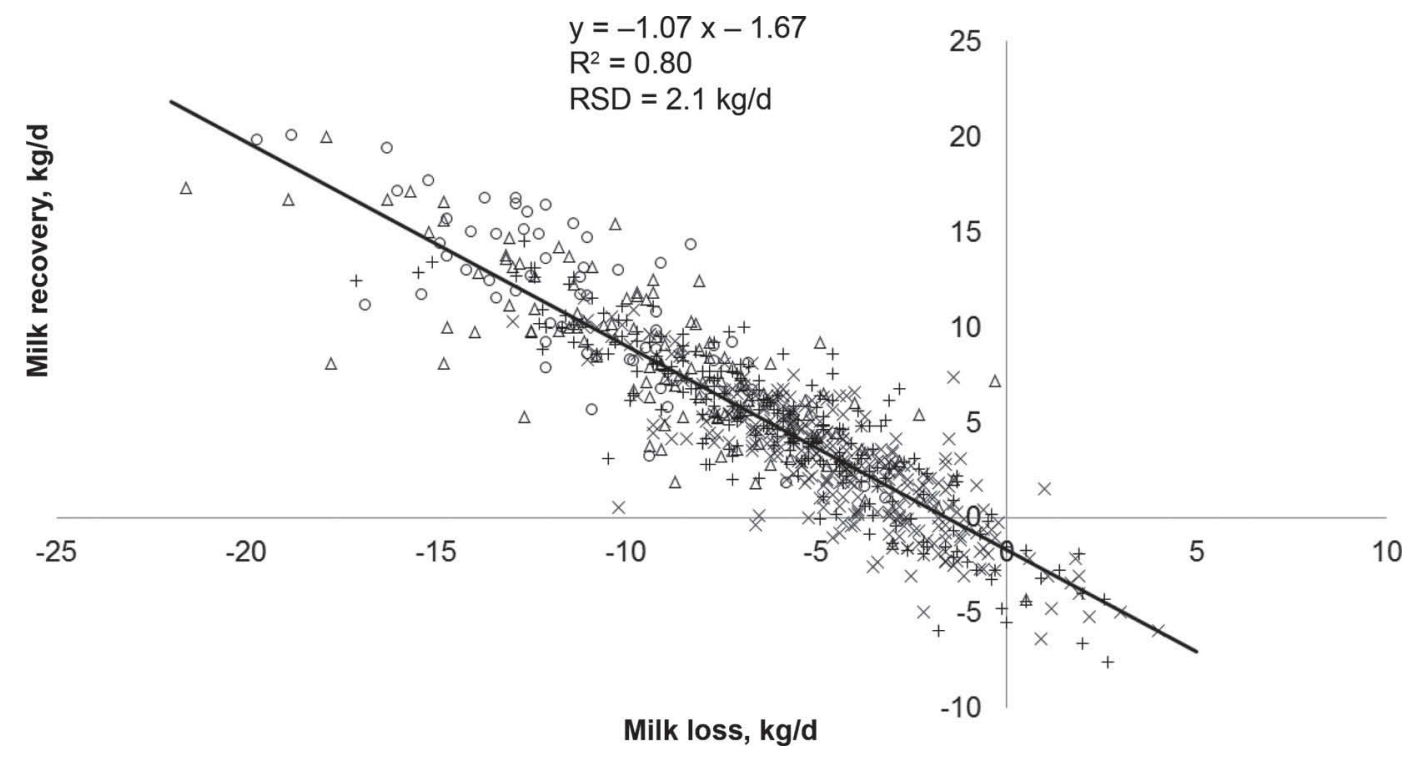

Figure 1. Individual milk yield loss and recovery of cows 2 wk after a 24 -h milking interval (24h-MI). RSD = residual standard deviation. Symbols represent cows that on day of $24 \mathrm{~h}-\mathrm{MI}$ presented a stage of lactation between 24 and 50 DIM (O), 51 and 100 DIM $(\Delta), 101$ and 180 $\operatorname{DIM}(+)$, and 181 and $311 \operatorname{DIM}(\times)$. 
Table 5. Effects of cows' potential milk yield level on absolute and relative milk yield loss, milk recovery, and rate of milk recovery (means $\pm \mathrm{SEM})^{1}$

\begin{tabular}{|c|c|c|c|c|}
\hline \multirow[b]{2}{*}{ Item } & \multicolumn{4}{|c|}{ Potential milk yield level } \\
\hline & $\begin{array}{l}\text { Lowest } 25 \% \\
\text { (1st quartile) }\end{array}$ & 2nd quartile & 3rd quartile & $\begin{array}{l}\text { Highest } 25 \% \\
\text { (4th quartile) }\end{array}$ \\
\hline $\begin{array}{l}\text { Milk yield loss, } \mathrm{kg} / \mathrm{d} \\
\text { Relative milk yield loss, } \% \\
\text { Milk yield recovery, } \mathrm{kg} / \mathrm{d} \\
\text { Milk yield recovery:loss ratio, }{ }^{2} \%\end{array}$ & $\begin{aligned}-6.6 & \pm 0.30^{\mathrm{a}} \\
-22.1 & \pm 1.0^{\mathrm{a}} \\
6.2 & \pm 0.35^{\mathrm{a}} \\
85.6 & \pm 3.7^{\mathrm{a}}\end{aligned}$ & $\begin{aligned}-7.7 & \pm 0.27^{\mathrm{b}} \\
-23.8 & \pm 0.9^{\mathrm{a}} \\
7.3 & \pm 0.32^{\mathrm{b}} \\
93.2 & \pm 3.0^{\mathrm{a}}\end{aligned}$ & $\begin{aligned}-9.0 & \pm 0.24^{\mathrm{c}} \\
-26.9 & \pm 0.8^{\mathrm{b}} \\
8.1 & \pm 0.29^{\mathrm{bc}} \\
89.6 & \pm 2.6^{\mathrm{a}}\end{aligned}$ & $\begin{aligned}-10.2 & \pm 0.31^{\mathrm{d}} \\
-28.4 & \pm 1.1^{\mathrm{b}} \\
9.0 & \pm 0.36^{\mathrm{c}} \\
86.3 & \pm 3.5^{\mathrm{a}}\end{aligned}$ \\
\hline
\end{tabular}

mary cistern when milked twice daily on control period (Knight and Dewhurst, 1994). This proportion is lower in early lactation than in the rest of lactation (Stelwagen et al., 2013) and could explain why cows in early lactation tend to lose more milk when omitting one milking compared with cows in mid and late lactation.

The prompter milk yield recovery of cows in early lactation observed in this study is noteworthy. Milk production is known to be regulated by both number and activity of MEC (Capuco et al., 2001, 2003). Singh et al. (2005) and Tremblay et al. (2009) determined that MEC apoptosis does not increase in the first 24 $\mathrm{h}$ after milking, and so we assume that the $24 \mathrm{~h}-\mathrm{MI}$ is insufficient to induce a decrease in MEC numbers. Similar studies have also found that proliferative MEC are more numerous (Capuco et al., 2001) and that MEC secretory activity is still increasing in early lactation compared with the declining phase of lactation (Capuco et al., 2003). This is also associated with a higher milking release of prolactin, the lactogenic and galactopoietic hormone, in early lactation (Koprowski and Tucker, 1973). All these early-lactation adaptive mechanisms could account for the faster recovery in milk yield observed in the present study for cows in early lactation.

Although parity did not significantly affect milk loss or recovery, primiparous cows showed greater relative losses in early and mid stages of lactation (Table 6). They also showed a greater milk recovery, leading to a greater recovery:loss ratio than cows in their second lactation (Table 7). To our knowledge, the influence of parity on cows' responses to a $24 \mathrm{~h}-\mathrm{MI}$ has not been reported in the literature. However, our finding of greater losses for primiparous cows is consistent with earlier findings using once-daily milking (Stelwagen et al., 2013). The effect of parity on recovery:loss ratio has not been studied to date. The higher recovery:loss ratio observed in primiparous cows in the present study might result from greater udder plasticity during the first months of lactation. A recent study showing similar results on milk losses on dairy ewes supports this hypothesis (Vanbergue et al., 2013).

Table 6. Effects of the interaction between stage of lactation and parity on absolute and relative milk yield loss and milk yield recovery (means \pm SEM)

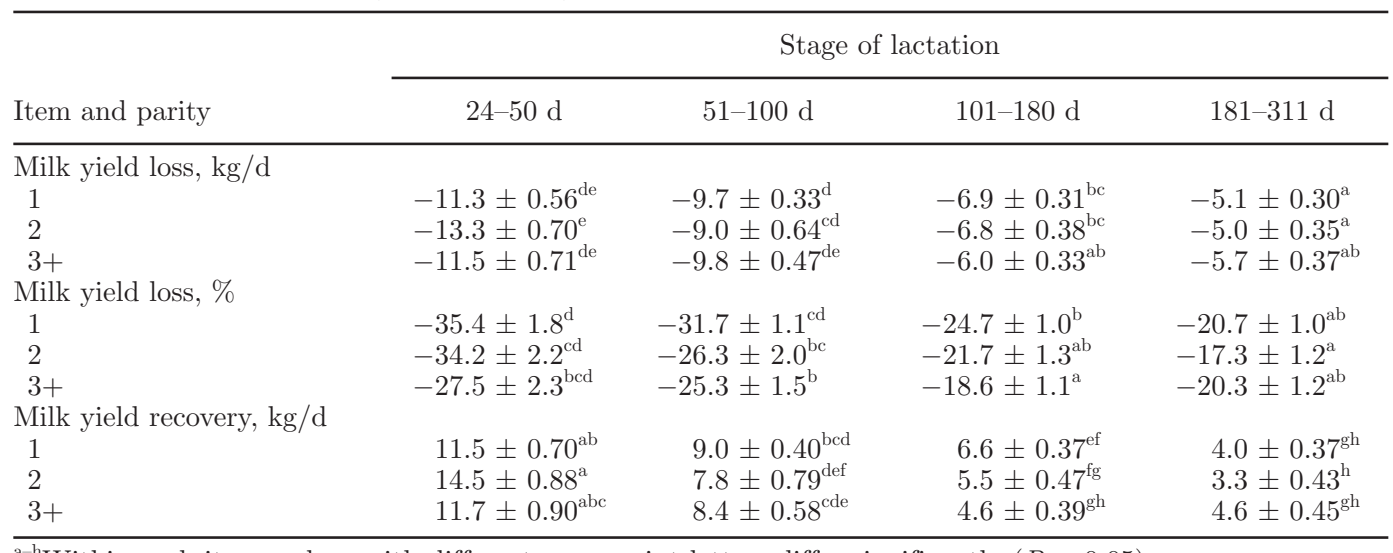

${ }^{\mathrm{a}-\mathrm{h}}$ Within each item, values with different superscript letters differ significantly $(P<0.05)$. 
Table 7. Effects of stage of lactation and parity on milk yield recovery:loss ratio (means $\pm \mathrm{SEM}$ )

\begin{tabular}{lc}
\hline Item & $\begin{array}{c}\text { Milk yield } \\
\text { recovery:loss ratio }(\%)\end{array}$ \\
\hline Stage of lactation & $99.0 \pm 5.6^{\mathrm{a}}$ \\
24 to $50 \mathrm{~d}$ & $88.7 \pm 3.1^{\mathrm{ab}}$ \\
51 to $100 \mathrm{~d}$ & $86.9 \pm 2.4^{\mathrm{ab}}$ \\
101 to $180 \mathrm{~d}$ & $79.8 \pm 2.9^{\mathrm{b}}$ \\
181 to $311 \mathrm{~d}$ & \\
Parity & $93.5 \pm 2.3^{\mathrm{a}}$ \\
1 & $84.1 \pm 3.2^{\mathrm{b}}$ \\
2 & $88.3 \pm 2.8^{\mathrm{ab}}$ \\
$3+$ &
\end{tabular}

${ }^{\mathrm{a}, \mathrm{b}}$ Within each factor, values with different superscript letters differ significantly $(P<0.05)$.

\section{CONCLUSIONS}

The 24h-MI caused an average milk yield loss of $24 \%$, higher than that reported in previous studies, with an average complete milk recovery after $2 \mathrm{~d}$. However, the average responses for milk loss and recovery were associated with a significant variability among cows. Stage of lactation, potential milk yield level, and parity accounted for the cows' response to the 24h-MI, but not for all the individual variability. Other factors therefore also determine the ability of dairy cows to adapt to $24 \mathrm{~h}-\mathrm{MI}$. The $57 \%$ relative milk loss (\%) repeatability observed in the present study suggests that the ability of the mammary gland to tolerate an extended milking interval of $24 \mathrm{~h}$ could be to some degree genetically determined.

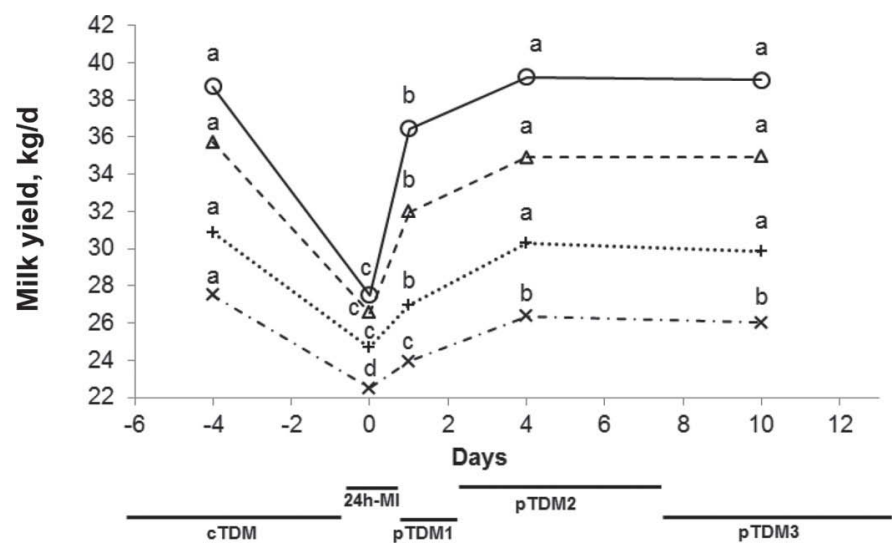

Figure 2. Time course of milk yield according to stage of lactation during experimental periods [twice daily milking control period (cTDM), a 24-h milking interval (24h-MI), d 1 after 24h-MI (pTDM1), d 2 to 6 after 24h-MI (pTDM2), and d 7 to 13 after 24h-MI (pTDM3)]. Values within the same stage of lactation with different letters differ at $P<0.05$. Symbols represent cows that on $24 \mathrm{~h}-\mathrm{MI}$ presented a stage of lactation between 24 and 50 DIM $(\bigcirc), 51$ and 100 DIM $(\Delta), 101$ and $180 \operatorname{DIM}(+)$, and 181 and 311 DIM $(\times)$.

\section{ACKNOWLEDGMENTS}

The authors thank A. Mottin and all the staff at the INRA experimental farm of Méjusseaume for help with animal care and handling. We are also grateful to G. Théaud and M. Fargetton for help in data collection. This study was funded by the INRA research unit PEGASE (St-Gilles, France).

\section{REFERENCES}

Auldist, M. J., and C. G. Prosser. 1998. Differential effects of shortterm once-daily milking on milk yield, milk composition and concentrations of selected blood metabolites in cows with low or high pasture intake. Pages 41-43 in Proc. New Zealand Society of Animal Production. Massey University, Palmerston North, New Zealand.

Ayadi, M., G. Caja, X. Such, and C. H. Knight. 2003. Effect of omitting one milking weekly on lactational performances and morphological udder changes in dairy cows. J. Dairy Sci. 86:2352-2358. http://dx.doi.org/10.3168/jds.S0022-0302(03)73828-4.

Capuco, A., S. Ellis, S. Hale, E. Long, R. Erdman, X. Zhao, and M. Paape. 2003. Lactation persistency: Insights from mammary cell proliferation studies. J. Anim. Sci. 81 (Suppl.):18-31.

Capuco, A., D. Wood, R. Baldwin, K. Mcleod, and M. Paape. 2001. Mammary cell number, proliferation, and apoptosis during a bovine lactation: Relation to milk production and effect of bST. J. Dairy Sci. 84:2177-2187. http://dx.doi.org/10.3168/jds.S00220302(01)74664-4.

Carruthers, V. R., S. R. Davis, A. M. Bryant, H. V. Henderson, C. A. Morris, and P. J. A. Copeman. 1993. Response of Jersey and Friesian cows to once a day milking and prediction of response based on udder characteristics and milk composition. J. Dairy Res. 60:1-11.

Davis, S. R., V. C. Farr, and K. Stelwagen. 1999. Regulation of yield loss and milk composition during once-daily milking: A review. Livest. Prod. Sci. 59:77-94. http://dx.doi.org/10.1016/S03016226(98)00204-8.

Elliott, G. M., F. H. Dodd, and P. J. Brumby. 1960. Variations in the rate of milk secretion in milking intervals of 2-24 hours. J. Dairy Res. 27:293-308.

Guinard-Flament, J., Y. Gallard, and H. Larroque. 2011a. Lactose in blood plasma and the ability of dairy cows to tolerate oncedaily milking in terms of milk loss and milk recovery. J. Dairy Sci. 94:3446-3454. http://dx.doi.org/10.3168/jds.2010-4081.

Guinard-Flament, J., S. Lemosquet, E. Delamaire, G. Le Bris, P. Lamberton, and C. Hurtaud. 2011b. Alteration of the nutrient uptake by the udder over an extended milking interval in dairy cows. J. Dairy Sci. 94:5458-5468. http://dx.doi.org/10.3168/jds.2011-4268.

Knight, C. H., and R. Dewhurst. 1994. Once-daily milking of dairycows: Relationship between milk loss and cisternal milk storage. J. Dairy Res. 61:441-449.

Koprowski, J. A., and H. A. Tucker. 1973. Serum prolactin during various physiological states and its relationship to milk production in the bovine. Endocrinology 92:1480-1487.

Labussière, J., and J. Coindet. 1968. Effets de la suppression de la traite du dimanche soir, chez les bovins de race française frisonne pie noire. Ann. Zootech. 17:231-244.

Lenth, R. 2014. lsmeans: Least-Squares Means. R package version 2.12. http://CRAN.R-project.org/package=lsmeans.

Meffe, N., C. Tache, and V. G. P. Marnet. 2003. Suppressing one milking per week throughout lactation of high producing dairy cows: Effects on animal performances and milk physico-chemical characteristics. Pages 85-88 in Rencontres Autour des Recherches sur les Ruminants, Paris, France, Dec. 2003. Institut de l'Elevage and INRA.

O'Brien, B., G. Ryan, W. Meaney, D. McDonagh, and A. Kelly. 2002. Effect of frequency of milking on yield, composition and pro- 
cessing quality of milk. J. Dairy Res. 69:367-374. http://dx.doi. org/10.1017/S0022029902005605.

Pinheiro, J., B. Bates, S. DedRoy, D. Sarkar, and the R Development Core Team. 2013. nlme: Linear and Nonlinear Mixed Effects Models. R package version 3.1-111.

Pomiès, D., and B. Rémond. 2000. Omission de une de deux traites par semaine sur des vaches laitières en milieu de lactation. Page 128 in 7èmes Rencontres Autour des Recherches sur les Ruminants, Paris, Fr. Dec. 2000. Institut de l'Elevage and INRA.

Radcliffe, J. C., L. F. Bailey, and M. L. Horne. 1973. Periodic omission of dairy cow milkings: I. Effect on milk yield and composition and on udder health. J. Dairy Res. 40:247-254.

Roguinsky, M., M. Ducelliez, and R. Borde. 1972. Effets de la suppression d'une traite par semaine sur l'infection mammaire et la production laitière. Ann. Rech. Vétérinaires 3:43-60.

Rupp, R., and D. Boichard. 1997. Genetic evaluation of dairy cattle for somatic cell count to improve mastitis resistance. Pages 211-214 in 4èmes Rencontres Autour des Recherches sur les Ruminants Paris, France, Dec. 1997. Institut l'Elevage and INRA, Paris, France.

Singh, K. J. Dobson, C. V. C. V. C. Phyn, S. R. R. Davis, V. C. C. Farr, A. J. J. Molenaar, and K. Stelwagen. 2005. Milk accumulation decreases expression of genes involved in cell-extracellular matrix communication and is associated with induction of apoptosis in the bovine mammary gland. Livest. Prod. Sci. 98:67-78. http://dx.doi.org/10.1016/j.livprodsci.2005.10.016.

Stelwagen, K., S. R. Davis, V. C. Farr, S. J. Eichler, and I. Politis. 1994. Effect of once daily milking and concurrent somatotropin on mammary tight junction permeability and yield of cows. J.
Dairy Sci. 77:2994-3001. http://dx.doi.org/10.3168/jds.S00220302(94)77240-4.

Stelwagen, K., V. C. Farr, G. D. Nicholas, S. R. Davis, and C. G. Prosser. 2008. Effect of milking interval on milk yield and quality and rate of recovery during subsequent frequent milking. Livest. Sci. 114:176-180. http://dx.doi.org/10.1016/j.livsci.2007.04.021.

Stelwagen, K., and S. Lacy-Hulbert. 1996. Effect of milking frequency on milk somatic cell count characteristics and mammary secretory cell damage in cows. Am. J. Vet. Res. 57:902-905.

Stelwagen, K., C. V. C. Phyn, S. R. Davis, J. Guinard-Flament, D. Pomiès, J. R. Roche, and J. K. Kay. 2013. Invited review: Reduced milking frequency: Milk production and management implications. J. Dairy Sci. 96:3401-3413. http://dx.doi.org/10.3168/jds.20126074 .

Tremblay, G., P. Bernier-Dodier, L. Delbecchi, G. F. Wagner, B. G. Talbot, and P. Lacasse. 2009. Local control of mammary involution: Is stanniocalcin-1 involved? J. Dairy Sci. 92:1998-2006. http://dx.doi.org/10.3168/jds.2008-1643.

Vanbergue, E., F. Barillet, C. Allain, P. Autran, M. R. Aurel, and O. Duvallon. 2013. Once daily milking ability of Lacaune dairy ewes: First zootechnical and physiological results. Pages 281-284 in 20èmes Rencontres Autour des Recherches sur les Ruminants, Paris, France. Dec. 2013. Institut de l'Elevage and INRA.

Wheelock, J. V., J. A. F. Rook, F. H. Dodd, and T. K. Griffin. 1966 The effect of varying the interval between milkings on milk secretion. J. Dairy Res. 33:161-176. http://dx.doi.org/10.1017/ S0022029900011833. 